\title{
In Vitro Study of Combined Application of Bevacizumab and 5-Fluorouracil or Bevacizumab and Mitomycin $C$ to Inhibit Scar Formation in Glaucoma Filtration Surgery
}

\author{
Yuanyuan Zhang, ${ }^{1}$ Shaopin $\mathrm{Zhu}^{2}{ }^{2} \mathrm{Xun} \mathrm{Xu} \mathbb{D}^{\mathrm{D}},{ }^{2}$ and Lei Zuo ${ }^{1}{ }^{1}$ \\ ${ }^{1}$ Department of Ophthalmology, Shanghai Fourth People's Hospital, Tongji University School of Medicine, \\ Shanghai 200081, China \\ ${ }^{2}$ Department of Ophthalmology, Shanghai General Hospital, Shanghai Jiao Tong University School of Medicine, \\ Shanghai 200080, China \\ Correspondence should be addressed to Lei Zuo; drzuolei@163.com
}

Received 9 June 2019; Revised 10 September 2019; Accepted 29 September 2019; Published 27 October 2019

Academic Editor: Sentaro Kusuhara

Copyright (c) 2019 Yuanyuan Zhang et al. This is an open access article distributed under the Creative Commons Attribution License, which permits unrestricted use, distribution, and reproduction in any medium, provided the original work is properly cited.

\begin{abstract}
This is an in vitro study conducted to observe the safety and antiscarring effects of combined application of bevacizumab (BVZ) and 5-fluorouracil (5-Fu) or BVZ and mitomycin C (MMC) during glaucoma filtration surgery (GFS). The cytotoxicity of drug combinations in human Tenon's fibroblasts (HTFs) and human umbilical vein endothelial cells (HUVECs) was evaluated. Their effects on the levels of vascular endothelial growth factor (VEGF) in HUVECs, cell proliferation and migration in HTFs, and the expression of collagen type I alpha 1 (Col1A1) gene in HTFs were evaluated. In addition, the effects of combined drugs on VEGF(R) mRNA in HTFs were detected to explore the possible underlying drug mechanisms. The results showed that BVZ combined with 5-Fu demonstrated more significant antiscarring effects than BVZ or 5-Fu alone. However, the inhibitory effects of BVZ combined with MMC were similar to those of MMC alone. The cytotoxicity of the drug combinations was significantly greater than that of single drug, suggesting that combined application of BVZ and antimetabolites after GFS was safer when applied at different sites (such as subconjunctival injection at bilateral sides of the filtering bleb) or at varied time points.
\end{abstract}

\section{Introduction}

The key to a successful outcome of glaucoma filtration surgery (GFS) is by achieving wound healing inhibition [1]. To reduce scar formation after trabeculectomy, maintain continuous filtration, and reduce intraocular pressure, antimetabolites such as 5-fluorouracil (5-Fu) and mitomycin C (MMC) are applied during surgery, which improves the success rate of the surgery to a certain extent [2]. In 2006, utilization of needle bleb revision with bevacizumab in a patient with a failing bleb following trabeculectomy is explored [3]. A subconjunctival injection of a certain dose of bevacizumab (BVZ) is given for inhibiting scar formation during trabeculectomy [4].

The concentration of vascular endothelial growth factor (VEGF) is increased for all ocular diseases such as neovascularization and/or inflammation, such as proliferative diabetic retinopathy [5], neovascular glaucoma [6], uveitis [7], and age-related macular degeneration [8]. In addition, VEGF is also associated with fibrosis and inflammation $[9,10]$ and plays an important role in scar formation after GFS [11].

VEGF induces proliferation of Tenon's fibroblasts in vitro during posttrabeculectomy wound healing process. Bevacizumab reduces the proliferation of fibroblasts in vitro and improves the surgical outcome [12]. Moreover, the water-tight suturing of the conjunctiva counteracts with BVZ-induced delayed healing of conjunctival wounds [13]. Subconjunctival injection of BVZ reaches an effective level in the intraocular tissues of the treated eyes [14]. Based on these studies, subconjunctival injection of a certain dose of BVZ for inhibiting scar formation during trabeculectomy has been used $[4,15,16]$.

As the scar formation after GFS involves complex processes of angiogenesis and fibrosis, it is inadequate to aim 
only on anti-VEGF or other single targets (such as antitransforming growth factor beta-2 and TGF- $\beta 2$ ) [17]. However, the use of antimetabolites is associated with several sight-threatening complications $[18,19]$. Therefore, clinicians have combined the application of BVZ and MMC or BVZ and 5-Fu to improve the clinical outcomes of GFS for refractory glaucoma $[20,21]$, trying to reduce the risk of antimetabolite use and effectively inhibit scar formation after GFS. Spitzer et al. [22] have reported on the toxicity of BVZ on human ocular cells; the safety of BVZ combined with 5-Fu $(\mathrm{BVZ}+5-\mathrm{Fu})$ and $\mathrm{BVZ}$ combined with $\mathrm{MMC}$ $(B V Z+M M C)$ in human ocular cells still remains unclear. The effects of BVZ combined with 5-Fu or MMC on VEGF levels in vascular endothelial cells on cell proliferation and migration and on collagen formation in human Tenon's fibroblasts (HTF) [23] are still rarely reported.

Hence, this study aimed to evaluate the safety and antiscarring effects of $\mathrm{BVZ}+5-\mathrm{Fu}$ and $\mathrm{BVZ}+\mathrm{MMC}$ in GFS through in vitro experiments. Also their effects on cytotoxicity, cell proliferation and migration, and collagen formation (collagen type I alpha l, Col1A1) [24] were observed, and their effects on VEGF and VEGF(R) mRNA were tested to explore the mechanisms of drug combinations. Our study assists in more comprehensively understanding the role of BVZ combined with antimetabolites during the wound healing process.

\section{Materials and Methods}

2.1. Cell Culture, Main Drugs, and Reagents. According to the Declaration of Helsinki, HTF cells were obtained from the specimens by excising the Tenon's capsule during strabismus surgery [24]. This study was approved by the Ethics Committee of Shanghai Fourth People's Hospital affiliated to Tongji University School of Medicine (Approval No. 2019012). Rabbit anti-human vimentin monoclonal antibodies $(1: 250, \mathrm{AB} 92547, \mathrm{Abcam})$ and rabbit anti-human keratin monoclonal antibodies (1:50, EPR17882, Abcam) were purchased from Abcam (Cambridge, England). HTF was cultured in Dulbecco's modified Eagle's medium (DMEM) supplemented with $10 \%$ fetal bovine serum and antibiotics. Human umbilical vein endothelial cells (HUVECs) (CRL-2873; American Type Culture Collection [ATCC]) were cultured in DMEM/F12 medium containing $10 \%$ fetal bovine serum and antibiotics. Culture media, antibiotics, trypsin $(1: 250)$, recombinant human vascular endothelial growth factor (VEGF), 4',6-diamidino-2-phenylindole (DAPI), 3-(4,5-dimethylthiazol-2-yl)-2,5-diphenyltetrazolium bromide (MTT), and heat-inactivated fetal bovine serum (FBS) were obtained from Invitrogen (Carlsbad, CA). Endothelial cell growth medium was purchased from PromoCell GmbH (Heidelberg, Germany). Bevacizumab (Avastin), phosSTOP, and protease inhibitors were obtained from Roche (Basel, Switzerland). The ELISA kit was brought from R\&D Systems (Minneapolis, Minnesota, USA). A Bradford protein assay kit was brought from Bio-Rad (Hercules, California, USA). Fluorouracil (25 mg/ $\mathrm{ml}$ ) was purchased from Shanghai XudongHaipu Pharmaceutical Co., Ltd., and mitomycin was purchased from
Zhejiang Haizheng Pharmaceutical Co., Ltd. Phosphate buffer solution (PBS) and $0.9 \%$ sodium chloride were obtained from Baxter Medical Products Co., Ltd.

\subsection{MTT Assay for Cytotoxicity/Proliferation of HUVECs and} HTF. Single cell suspension cultured under normal conditions at logarithmic growth phase was inoculated into 6well culture plates at a density of $5 \times 10^{4}$ per well and synchronized with serum-free RPMI 1640 medium. HUVECs were incubated with BVZ, 5-Fu, MMC, BVZ/5-Fu, BVZ/MMC, or PBS (control) for $24 \mathrm{~h}$, and HTF cells were incubated with BVZ, 5-Fu, MMC, BVZ/5-Fu, BVZ/MMC, or PBS (control) for $24 \mathrm{~h}$ (the concentrations of medications are shown in Table 1). The cells were rinsed with PBS and then fresh serum-free medium with or without $0.5 \mathrm{mg} / \mathrm{mL}$ MTT was added into the cells. After $2 \mathrm{~h}$ of incubation, an amount of formazan was extracted and colorimetric assay of ELISA (Emax, Molecular Devices Corporation, Sunnyvale, California, USA) was performed to determine the absorbance value per well at $570 \mathrm{~nm}$ [25].

2.3. Determination of VEGF Levels in HUVECs. HUVECs were treated with $5-\mathrm{Fu}(0.5 \mathrm{mg} / \mathrm{ml}), \mathrm{MMC}(0.0002 \mathrm{mg} / \mathrm{ml})$, BVZ $(0.25 \mathrm{mg} / \mathrm{ml}), 5-\mathrm{Fu}(0.5 \mathrm{mg} / \mathrm{ml})+\mathrm{BVZ}(0.25 \mathrm{mg} / \mathrm{ml})$, MMC $(0.0002 \mathrm{mg} / \mathrm{ml})+B V Z(0.25 \mathrm{mg} / \mathrm{ml})$, or PBS. After $24 \mathrm{~h}, 200 \mu \mathrm{l}$ of supernatant was collected from each well and analyzed by a VEGF ELISA kit (R\&D Systems, USA) according to the manufacturer's instructions [26].

2.4. Analysis of HTF Cell Migration. When the HTFs reached $80 \%$ confluence in vitro, then scratches were drawn vertical to that of a pre-drawn line with a $1 \mathrm{~mm}$ tip at the bottom of the culture dish, and 3 scratches were drawn with the same distance. The cells that were floating along the scratches were washed with PBS, photographed under a microscope (microscope: Leica DM IRB, magnification ratio $\times 40$ ), and the time point was recorded as $0 \mathrm{~h}$. A total of 6 images at different fields of view were taken. This was followed by the addition of $0.2 \%$ FBS medium and treatment of cells with 5$\mathrm{Fu}(0.5 \mathrm{mg} / \mathrm{ml}), \mathrm{MMC}(0.0002 \mathrm{mg} / \mathrm{ml}), \mathrm{BVZ}(0.25 \mathrm{mg} / \mathrm{ml})$, $5-\mathrm{Fu}(0.5 \mathrm{mg} / \mathrm{ml})+\mathrm{BVZ}(0.25 \mathrm{mg} / \mathrm{ml})$, or MMC $(0.0002 \mathrm{mg} /$ $\mathrm{ml})+\mathrm{BVZ}(0.25 \mathrm{mg} / \mathrm{ml})$. Then, $30 \mathrm{ng} / \mathrm{ml} \mathrm{VEGF}$ was added into the treatments, while $30 \mathrm{ng} / \mathrm{mL}$ of VEGF alone was added into $0.2 \%$ FBS culture medium, which acts as a positive control. The culture medium without drug intervention was set as the blank control group. The cells were further cultured and images were taken after culturing for $24 \mathrm{~h}$. The same region was selected for each repetition when taking the photographs. Image J software was used for analyzing the scratch area. The wound closure rate was calculated using the formula: wound closure rate $=$ (area of the wound at $0 \mathrm{~h}$-area of the wound at $24 \mathrm{~h}$ )/area of the wound at $0 \mathrm{~h} \mathrm{[27].}$

2.5. Quantitative Polymerase Chain Reaction (PCR) Analysis of Collagen (Col1A1) and VEGF(R) mRNA in HTF. HTF cells were cultured in vitro, and the expression of VEGF, 
TABle 1: Human Tenon's fibroblasts (HTFs) and human umbilical vein endothelial cells (HUVECs) were incubated with different concentrations of bevacizumab (BVZ), 5-fluorouracil (5-Fu), BVZ/ 5-Fu, mitomycin C (MMC), and BVZ/MMC for cytotoxicity analyses.

\begin{tabular}{|c|c|c|c|c|}
\hline & $\begin{array}{r}\text { Medi } \\
\text { conc } \\
(\mathrm{m}\end{array}$ & $\begin{array}{l}\text { ne and } \\
\text { tration } \\
\text { ml) }\end{array}$ & $\begin{array}{r}\text { Medicine and co } \\
(\mathrm{mg} / \mathrm{m}\end{array}$ & ntration \\
\hline & & 0.025 & & \\
\hline & BVZ & 0.25 & & \\
\hline & & 2.5 & & \\
\hline & & 0.05 & & 0.05 \\
\hline HTF & $5-\mathrm{Fu}$ & 0.5 & BVZ 0.25/5-Fu & 0.5 \\
\hline & & 5 & & 5 \\
\hline & & 0.00002 & & 0.00002 \\
\hline & MMC & 0.0002 & BVZ 0.25/MMC & 0.0002 \\
\hline & & 0.002 & & 0.002 \\
\hline & & 0.025 & & \\
\hline & $\mathrm{BVZ}$ & 0.25 & & \\
\hline & & 2.5 & & \\
\hline & & 0.05 & & 0.05 \\
\hline HUVEC & $5-\mathrm{Fu}$ & 0.5 & BVZ 2.5/5-Fu & 0.5 \\
\hline & & 5 & & 5 \\
\hline & & 0.00002 & & 0.00002 \\
\hline & MMC & 0.0002 & BVZ 2.5/MMC & 0.0002 \\
\hline & & 0.002 & & 0.002 \\
\hline
\end{tabular}

VEGFR1 (Flt-1), VEGFR2 (KDR), and collagen (Col1A1) mRNA was quantified using PCR $(n=3)$. The cells were treated with $5-\mathrm{Fu}(0.5 \mathrm{mg} / \mathrm{ml}), \mathrm{MMC}(0.0002 \mathrm{mg} / \mathrm{ml}), \mathrm{BVZ}$ $(0.25 \mathrm{mg} / \mathrm{ml}), 5-\mathrm{Fu}(0.5 \mathrm{mg} / \mathrm{ml})+\mathrm{BVZ}(0.25 \mathrm{mg} / \mathrm{ml}), \mathrm{MMC}$ $(0.0002 \mathrm{mg} / \mathrm{ml})+$ BVZ $(0.25 \mathrm{mg} / \mathrm{ml})$, or PBS. The total mRNA was extracted by using TRIzol reagent (Invitrogen, Carlsbad, CA). cDNA was then synthesized by reverse transcription (Tetro cDNA Synthesis Kit, Bioline, London, UK), and mRNA was detected by RT-PCR (SensiFAST ${ }^{\mathrm{TM}}$ SYBR ${ }^{\circledR}$ Hi-ROX Kit, Bioline, London, UK) by using a special software (ABI Prism 7500 SDS Software, USA). The primers and probes for RT-PCR (Table 2) were designed by Shanghai Generay Biotech CO., Ltd. The expression levels of VEGF, Flt-1, KDR, and Col1A1 mRNA were normalized to glyceraldehyde-3-phosphate dehydrogenase (GAPDH) mRNA.

2.6. Statistical Analysis. The variables were described as mean \pm standard deviation. If the variance was homogeneous, then least significant difference (LSD) and Student-Newman-Keuls (SNK) tests were used for analysis of variance. If the differences were homogeneous, the differences between the experimental groups were analyzed by using the rank sum test. All statistical analyses were performed by using SPSS 19.0 (SPSS Inc., IL, USA). $P<0.05$ was considered to be statistically significant.

\section{Results}

3.1. Identification of HTF. Immunofluorescence assay was performed to identify HTF cells. The result of staining of anti-vimentin antibody was positive, anti-keratin antibody was negative, and morphological observation of these cells confirmed them as fibroblasts [28] (see Figure 1).
TABle 2: Primers used in real-time polymerase chain reaction.

\begin{tabular}{lc}
\hline Gene name & \multicolumn{1}{c}{ Primer sequences } \\
\hline \multirow{2}{*}{ VEGF } & Forward: 5'-ATCGAGTACATCTTCAAGCCAT-3' \\
& Reverse: 5'-GTGAGGTTTGATCCGCATAATC-3' \\
Flt-1 & Forward: 5'-CAAGATTTGCAGAACTTGTGGA-3' \\
& Reverse: 5'-CTGTCAGTATGGCATTGATTGG-3' \\
KDR & Forward: 5'-GGAGCTTAAGAATGCATCCTTG-3' \\
& Reverse: 5'-GATGCTTTCCCCAATACTTGTC-3' \\
Col1A1 & Forward: 5'-AAAGATGGACTCAACGGTCTC-3' \\
& Reverse: 5'-CATCGTGAGCCTTCTCTTGAG-3' \\
GAPDH & Forward: 5'-AGACAGCCGCATCTTCTTGT-3' \\
& Reverse: 5'-CTTGCCGTGGGTAGAGTCAT-3' \\
\hline
\end{tabular}

3.2. Cytotoxicity in HTFs and HUVECs. After BVZ $0.025 \mathrm{mg} /$ $\mathrm{ml}$ was added to the cultured HTFs, no significant cytotoxicity was observed when compared with that in the PBS group. With increasing concentration of BVZ from 0.25 to $2.5 \mathrm{mg} / \mathrm{ml}$, cytotoxicity showed a significant increase. In the groups of MMC $0.0002,0.002$, and $0.02 \mathrm{mg} / \mathrm{ml}$ with BVZ $0.25 \mathrm{mg} / \mathrm{ml}$, the survival ability of HTF cells was significantly lower than that in the MMC intervention group. After adding BVZ $0.25 \mathrm{mg} / \mathrm{ml}$ to $5-\mathrm{Fu} 0.05,0.5$, and $5 \mathrm{mg} / \mathrm{ml}$, the number of dead HTFs was also relatively increased.

For HUVECs, after the addition of $0.025,0.25$, and $2.5 \mathrm{mg} / \mathrm{mL} \mathrm{BVZ}$, the viability of HUVECs was not significantly lower than that in the PBS group. After addition of BVZ $2.5 \mathrm{mg} / \mathrm{ml}$ to MMC $0.0002,0.002$, and $0.02 \mathrm{mg} / \mathrm{ml}$ group and addition of BVZ $2.5 \mathrm{mg} / \mathrm{ml}$ to $5-\mathrm{Fu} 0.05,0.5$, and $5 \mathrm{mg} / \mathrm{ml}$ group, the number of dead HUVECs was significantly increased than that in the 5-Fu or MMC groups without BVZ (see Figure 2 and Tables 3 and 4).

3.3. VEGF Levels in HUVECs. HUVECs were cultured for 24 hours, and the VEGF levels in the control group and 5-Fu $(0.5 \mathrm{mg} / \mathrm{ml})$, MMC $(0.0002 \mathrm{mg} / \mathrm{ml}), B V Z(0.25 \mathrm{mg} / \mathrm{ml}), 5-\mathrm{Fu}$ $(0.5 \mathrm{mg} / \mathrm{ml})+B V Z(0.25 \mathrm{mg} / \mathrm{ml})$, and $\mathrm{MMC}(0.0002 \mathrm{mg} /$ $\mathrm{ml})+\mathrm{BVZ}(0.25 \mathrm{mg} / \mathrm{ml})$ groups were $42.8 \pm 0.12,10.8 \pm 0.21$, $6.67 \pm 0.23,1.18 \pm 0.11,4.95 \pm 0.26$, and $4.27 \pm 0.28 \mathrm{pg} / \mathrm{ml}$, respectively. The levels of VEGF in HUVECs of BVZ, 5-Fu, and $M M C$ intervention groups were significantly lower than those of the control group. However, the levels of VEGF in 5$\mathrm{Fu}$ or MMC group with the addition of BVZ were significantly lower than those in the 5-Fu or MMC group without BVZ (Figure 3).

3.4. Cell Migration in HTFs. The relative rate of HTF cell migration at 24 hours in $5-\mathrm{Fu}(0.5 \mathrm{mg} / \mathrm{ml})+\mathrm{BVZ}(0.25 \mathrm{mg} /$ $\mathrm{ml}), \quad 5-\mathrm{Fu} \quad(0.5 \mathrm{mg} / \mathrm{ml}), \quad$ BVZ $\quad(0.25 \mathrm{mg} / \mathrm{ml}), \quad$ MMC $(0.0002 \mathrm{mg} / \mathrm{ml})+$ BVZ $(0.25 \mathrm{mg} / \mathrm{ml})$, MMC $(0.0002 \mathrm{mg} / \mathrm{ml})$ (both simultaneously adding VEGF $30 \mathrm{ng} / \mathrm{ml}$ or only VEGF $30 \mathrm{ng} / \mathrm{ml}$ ) groups, and the blank control group was $0.0132 \pm 0.0005, \quad 0.0182 \pm 0.0009, \quad 0.0227 \pm 0.0006$, $0.0148 \pm 0.0001, \quad 0.0101 \pm 0.0014, \quad 0.0790 \pm 0.0023, \quad$ and $0.0439 \pm 0.0018$, respectively. Both drug intervention and combined drug intervention showed significant inhibitory effects on HTF cell migration. The relative rate of cell migration in the $\mathrm{BVZ}+5-\mathrm{Fu}$ group showed no significant 

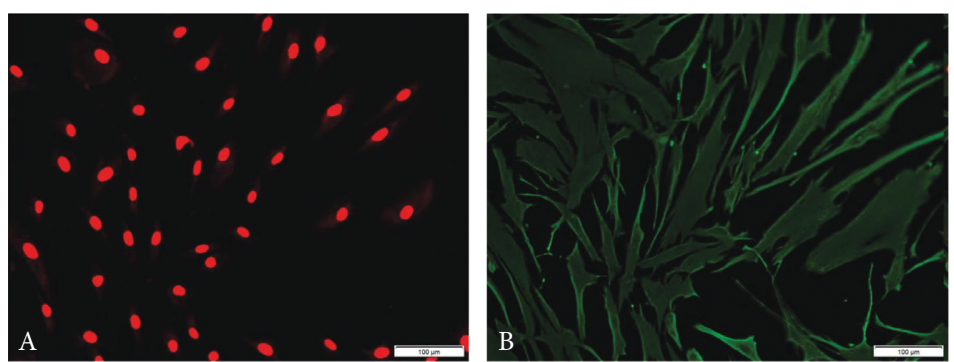

(a)
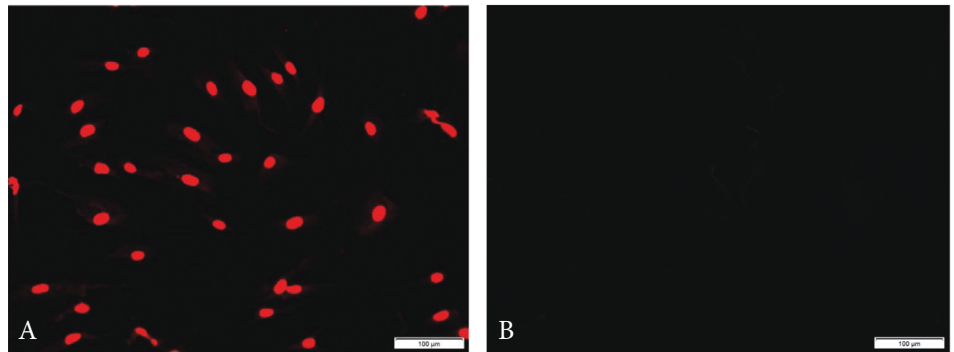

(b)
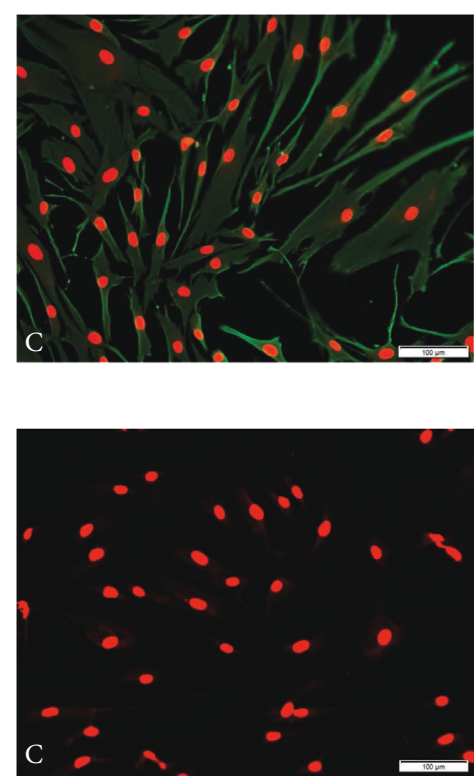

FIGURE 1: Identification of fibroblasts by immunofluorescence assay (magnification ratio $\times 200$ ). (a). The nucleus of cells stained with DAPI showed red fluorescence (A), the cytoplasm of cells stained with anti-vimentin antibody showed green fluorescence (B), and combined staining images of nucleus and cytoplasm (C). (b). The nucleus stained by DAPI showed red fluorescence (A), while the cytoplasm stained with anti-keratin antibody was negative (B), and the combination of nucleus and cytoplasm staining images (C).

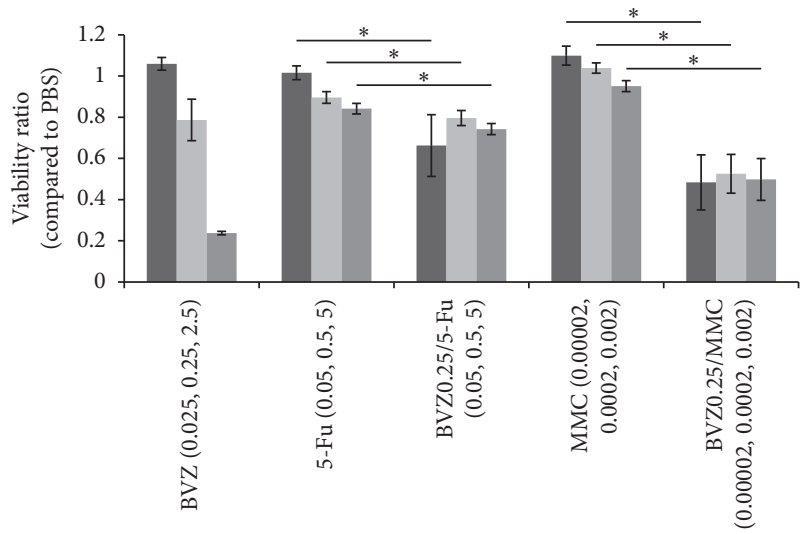

(a)

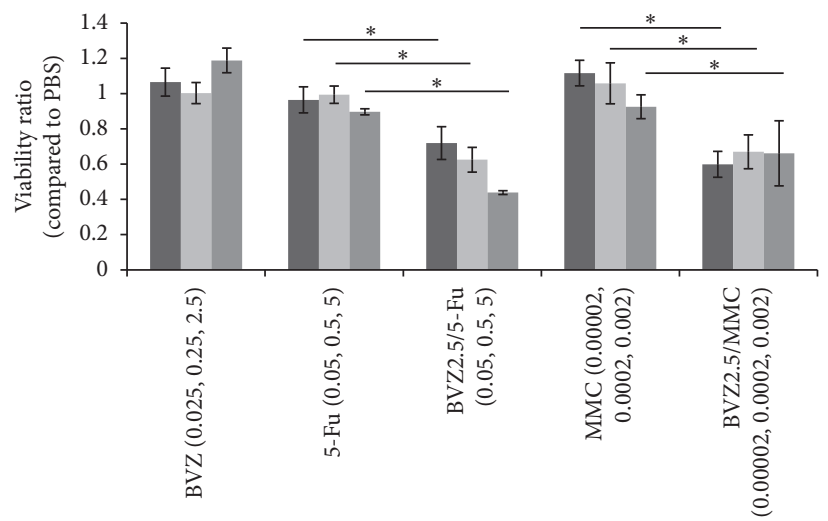

(b)

FIgURE 2: Cell viability of human Tenon's fibroblasts (HTFs) and human umbilical vein endothelial cells (HUVECs) after treatment with bevacizumab (BVZ), mitomycin C (MMC), 5-fluorouracil (5-Fu), BVZ/MMC, and BVZ/5-Fu. The cell viability of the control group was set to $100 \%$. Unit: $\mathrm{mg} / \mathrm{ml} .{ }^{*} \mathrm{P}<0.05$. (a) Toxicity assay of HTF $(24 \mathrm{~h})$. (b) Toxicity assay of HUVEC $(24 \mathrm{~h})$.

TABLE 3: Cell viability of human Tenon's fibroblasts (HTFs) after treatment with bevacizumab (BVZ), 5-fluorouracil (5-Fu), BVZ/5-Fu, mitomycin C (MMC), and BVZ/MMC.

\begin{tabular}{|c|c|c|c|c|c|}
\hline \multicolumn{2}{|c|}{$\begin{array}{l}\text { Medicine and } \\
\text { concentration } \\
(\mathrm{mg} / \mathrm{ml})\end{array}$} & \multirow{2}{*}{$\begin{array}{c}\text { Absorbance at } 570 \mathrm{~nm} \text { (ratio, compared to } \\
\text { PBS) } \\
1.0596 \pm 0.0307\end{array}$} & \multicolumn{2}{|c|}{$\begin{array}{l}\text { Medicine and } \\
\text { concentration }(\mathrm{mg} / \mathrm{ml})\end{array}$} & \multirow[t]{2}{*}{$\begin{array}{c}\text { Absorbance at } 570 \mathrm{~nm} \text { (ratio, compared to } \\
\text { PBS) }\end{array}$} \\
\hline \multirow{3}{*}{$\mathrm{BVZ}$} & 0.025 & & \multirow{6}{*}{$\mathrm{BVZ0.25/5-Fu}$} & \multirow[b]{4}{*}{05} & \\
\hline & 0.25 & $0.7871 \pm 0.1008$ & & & \\
\hline & 2.5 & $0.2376 \pm 0.0084$ & & & \\
\hline \multirow{3}{*}{$5-\mathrm{Fu}$} & 0.05 & $1.0161 \pm 0.0335$ & & & $0.6626 \pm 0.1499$ \\
\hline & 0.5 & $0.8961 \pm 0.0284$ & & 0.5 & $0.7962 \pm 0.0365$ \\
\hline & 5 & $0.8417 \pm 0.0258$ & & 5 & $0.7426 \pm 0.0270$ \\
\hline \multirow{3}{*}{ MMC } & 0.00002 & $1.0994 \pm 0.0461$ & \multirow{3}{*}{$\begin{array}{l}\text { BVZ0.25/ } \\
\text { MMC }\end{array}$} & 0.00002 & $0.4837 \pm 0.1337$ \\
\hline & 0.0002 & $1.0390 \pm 0.0250$ & & 0.0002 & $0.5255 \pm 0.0942$ \\
\hline & 0.002 & $0.9512 \pm 0.0266$ & & 0.002 & $0.4980 \pm 0.1015$ \\
\hline
\end{tabular}


TABLE 4: Cell viability of human umbilical vein endothelial cells (HUVECs) after treatment with bevacizumab (BVZ), 5-fluorouracil (5-Fu), $\mathrm{BVZ} / 5-\mathrm{Fu}$, mitomycin C (MMC), and BVZ/MMC.

\begin{tabular}{|c|c|c|c|c|c|}
\hline \multicolumn{2}{|c|}{$\begin{array}{l}\text { Medicine and } \\
\text { concentration } \\
(\mathrm{mg} / \mathrm{ml})\end{array}$} & \multirow{2}{*}{$\begin{array}{c}\text { Absorbance at } 570 \mathrm{~nm} \text { (ratio, compared to } \\
\text { PBS) } \\
1.0652 \pm 0.0792\end{array}$} & \multicolumn{2}{|c|}{$\begin{array}{c}\text { Medicine and } \\
\text { concentration }(\mathrm{mg} / \mathrm{ml})\end{array}$} & \multirow[t]{2}{*}{$\begin{array}{l}\text { Absorbance at } 570 \mathrm{~nm} \text { (ratio, compared to } \\
\text { PBS) }\end{array}$} \\
\hline \multirow{3}{*}{$\mathrm{BVZ}$} & 0.025 & & \multirow{6}{*}{$\mathrm{BVZ2.5/5-Fu}$} & & \\
\hline & 0.25 & $1.0030 \pm 0.0598$ & & & \\
\hline & 2.5 & $1.1882 \pm 0.0699$ & & & \\
\hline \multirow{3}{*}{$5-\mathrm{Fu}$} & 0.05 & $0.9645 \pm 0.0739$ & & 0.05 & $0.7194 \pm 0.0929$ \\
\hline & 0.5 & $0.9938 \pm 0.0492$ & & 0.5 & $0.6249 \pm 0.0701$ \\
\hline & 5 & $0.8967 \pm 0.0172$ & & 5 & $0.4385 \pm 0.0108$ \\
\hline \multirow{3}{*}{ MMC } & 0.00002 & $1.1165 \pm 0.0726$ & \multirow{3}{*}{$\begin{array}{l}\text { BVZ2.5/ } \\
\text { MMC }\end{array}$} & 0.00002 & $0.5989 \pm 0.0734$ \\
\hline & 0.0002 & $1.0582 \pm 0.1162$ & & 0.0002 & $0.6698 \pm 0.0960$ \\
\hline & 0.002 & $0.9254 \pm 0.0676$ & & 0.002 & $0.6613 \pm 0.1846$ \\
\hline
\end{tabular}

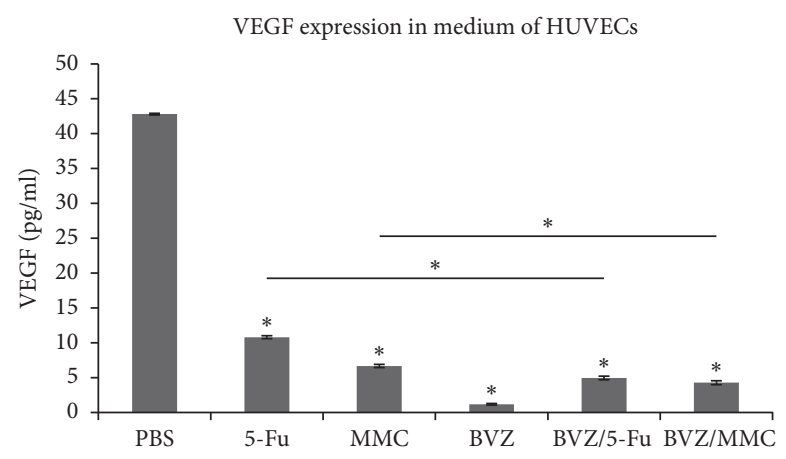

FIGURE 3: Effect of 5-fluorouracil (5-Fu), mitomycin C (MMC), bevacizumab (BVZ), BVZ/5-Fu, and BVZ/MMC on vascular endothelial growth factor (VEGF) levels in human umbilical vein endothelial cells (HUVECs) ${ }^{*} P<0.05$.

differences from that of the MMC or BVZ + MMC group. However, the relative rate of cell migration in the MMC group was significantly lower than the BVZ + MMC group. The relative rate of cell migration in the $\mathrm{BVZ}+5-\mathrm{Fu}$ group was significantly lower than that of the BVZ or 5-Fu groups (see Figure 4 and Table 5).

3.5. Col1A1 mRNA Expression in HTF. The levels of Col1A1 mRNA expression in HTFs that were cultured for 24 hours in the control group and 5-Fu, MMC, BVZ, BVZ+5-Fu, and $\mathrm{BVZ}+\mathrm{MMC}$ groups were $0.0450 \pm 0.0003,0.0654 \pm 0.0020$ $0.0055 \pm 0.0000, \quad 0.0110 \pm 0.0001, \quad 0.0053 \pm 0.0001, \quad$ and $0.0063 \pm 0.0003$, respectively. Except for $5-\mathrm{Fu}$ group, both drug intervention and combined drug interventions significantly inhibited Col1A1 mRNA expression in HTF cells. The suppression of collagen formation by $\mathrm{BVZ}+5-\mathrm{Fu}$ was significantly greater than 5-Fu or BVZ, while the inhibition of collagen production by BVZ + MMC showed no significant differences from that of $\mathrm{MMC}$ or $\mathrm{BVZ}+5$-Fu (see Figure 5).

3.6. $\operatorname{VEGF}(R)$ mRNA Expression in HTFs. VEGFR1(Flt-1) mRNA expression levels of HTFs cultured for 24 hours in the blank control group and 5-Fu, MMC, BVZ, BVZ + 5-Fu, and $\mathrm{BVZ}+\mathrm{MMC}$ groups were 2.388 \pm 0.0500 , $4.137 \pm 0.0678,1.412 \pm 0.0211,0.408 \pm 0.0040,0.569 \pm 0.0139$, and $0.294 \pm 0.0039$, respectively; VEGFR2(KDR) mRNA expression levels were $0.279 \pm 0.0074, \quad 0.120 \pm 0.0010$, $0.017 \pm 0.0003, \quad 0.078 \pm 0.0020, \quad 0.009 \pm 0.0002, \quad$ and $0.008 \pm 0.0001$, respectively; and VEGF mRNA expression levels were $0.3329 \pm 0.0072,0.4306 \pm 0.0032,0.0521 \pm 0.0005$, $0.0095 \pm 0.0003,0.0050 \pm 0.0001$, and $0.0064 \pm 0.0003$, respectively. Except for the 5-Fu group, both drug intervention and combined drug intervention significantly downregulated $\operatorname{VEGF}(\mathrm{R})$ mRNA expression in HTFs. 5-Fu significantly inhibited VEGFR2 mRNA expression in HTFs only. The inhibitory effects of $\mathrm{BVZ}+5$-Fu or $\mathrm{BVZ}+\mathrm{MMC}$ combined drugs were greater than those of $5-\mathrm{Fu}$ or $\mathrm{MMC}$ single drug. However, the inhibitory effects of BVZ $+5-\mathrm{Fu}$ showed no significant differences when compared with those of $\mathrm{BVZ}+\mathrm{MMC}$ on VEGF mRNA and VEGFR2 mRNA expression in HTFs (see Figure 6).

\section{Discussion}

This in vitro study was conducted to investigate the safety of $\mathrm{BVZ}+5-\mathrm{Fu}$ and $\mathrm{BVZ}+\mathrm{MMC}$ and their inhibitory effects on scar formation after GFS. The cytotoxicity of BVZ +5-Fu and BVZ + MMC on HTFs and HUVECs was examined. The results reveal that $\mathrm{BVZ}+5-\mathrm{Fu}$ and $\mathrm{BVZ}+\mathrm{MMC}$ can significantly inhibit the VEGF levels in HUVECs, prolong the proliferation and migration of HTFs, and inhibit the formation of collagen (Col1A1) in HTFs. Also, the effect of combined drugs on $\operatorname{VEGF}(\mathrm{R})$ mRNA in HTF cells was observed. 

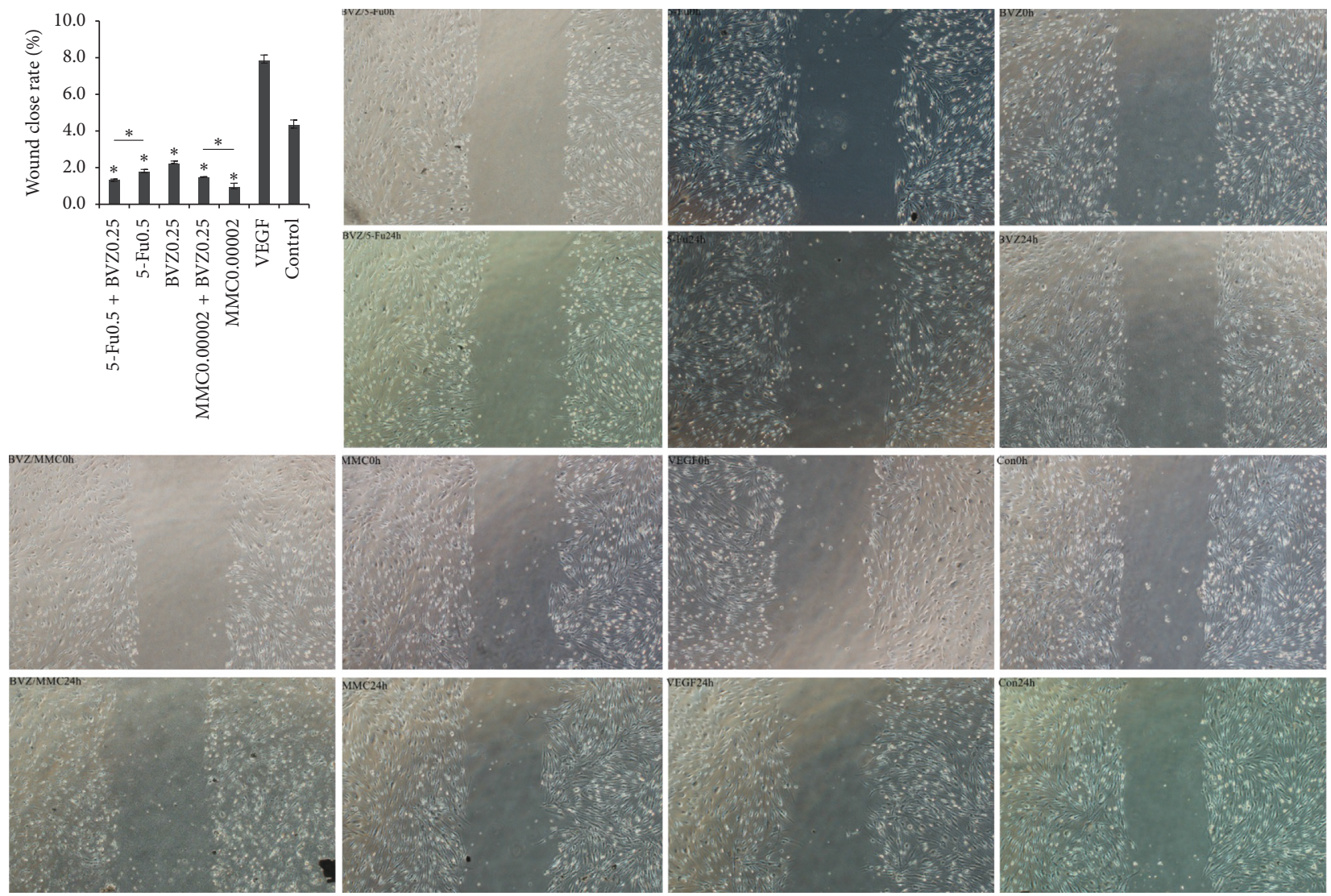

FIgURE 4: Cell migration analysis. The scratch-wound assays showed the effect of 5-fluorouracil (5-Fu), mitomycin C (MMC), bevacizumab (BVZ), BVZ + 5-Fu, and BVZ + MMC on cell migration of human Tenon's fibroblasts (HTFs) under the action of vascular endothelial growth factor (VEGF) (magnification ratio $\times 40$ ). ${ }^{*} P<0.05$.

TABLE 5: Multiple comparison analysis showing the differences in the relative cell migration rate of human Tenon's fibroblasts (HTFs) in each group.

\begin{tabular}{lccccccc}
\hline Group & $\begin{array}{c}\text { BVZ +5-Fu } \\
P \text { value }\end{array}$ & $\begin{array}{c}5 \text {-Fu } \\
P \text { value }\end{array}$ & $\begin{array}{c}\text { BVZ } \\
P \text { value }\end{array}$ & $\begin{array}{c}\text { BVZ+ MMC } \\
P \text { value }\end{array}$ & $\begin{array}{c}\text { MMC } \\
P \text { value }\end{array}$ & $\begin{array}{c}\text { VEGF } \\
P \text { value }\end{array}$ & $P$ value \\
\hline BVZ+5-Fu & - & 0.001 & $<0.0001$ & 0.066 & 0.099 & $<0.0001$ \\
5 -Fu & 0.001 & - & 0.001 & 0.019 & $<0.0001$ & $<0.0001$ \\
BVZ & $<0.0001$ & 0.001 & - & 0.002 & $<0.0001$ & $<0.0001$ \\
BVZ+ MMC & 0.066 & 0.019 & 0.002 & - & 0.027 & $<0.0001$ & $<0.0001$ \\
MMC & 0.099 & $<0.0001$ & $<0.0001$ & 0.027 & - & $<0.0001$ \\
VEGF & $<0.0001$ & $<0.0001$ & $<0.0001$ & $<0.0001$ & $<0.0001$ & - \\
Con & $<0.0001$ & $<0.0001$ & $<0.0001$ & $<0.0001$ & $<0.0001$ & $<0.0001$ & $<0.0001$ \\
\hline
\end{tabular}

Note. BVZ: bevacizumab; 5-Fu: 5-fluorouracil; MMC: mitomycin C; VEGF: vascular endothelial growth factor; Con: control.

The surgical goal of GFS is to create an incision to bypass the trabecular meshwork and drain the aqueous humor outwards through subconjunctival filtering blebs, thereby relieving the elevated intraocular pressure [29]. Increased angiogenesis in the conjunctiva and migration of fibroblasts lead to fibroblast proliferation and concomitant collagen deposition, directly causing filtering bleb failure [30]. Angiogenesis is defined as a process of formation of new blood vessels from the existing blood vessels. It is an important process that occurs naturally during growth, reproduction, and wound healing in order to supply nutrients and oxygen to the tissues [31]. VEGF is considered to be the most common stimulator of endothelial growth and vascular permeability and might be the link between angiogenesis and scar formation [11]. VEGF not only regulates fibrosis via angiogenesis, but also acts as a mediator in signaling pathways, promoting fibroblast migration, proliferation, and collagen production $[31,32]$. The wound healing response can be divided into two different stages in a mouse GFS model [33]. The early "acute inflammation" phase, which is characterized by a marked increase in the transcriptional expression of VEGF, chemokine (C-X-C motif) ligand (CXCL), and matrix metalloproteinase (MMP), as well as increased inflammatory cell infiltration. The "late fibrosis" 


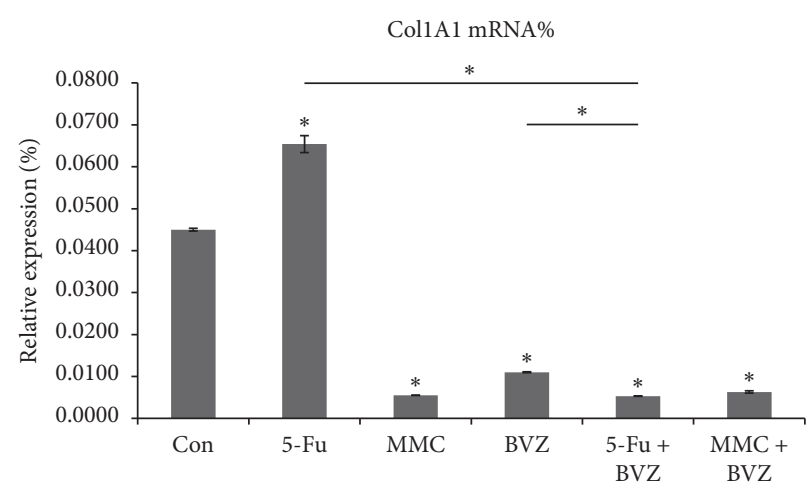

Figure 5: Effect of 5-fluorouracil (5-Fu), mitomycin C (MMC), bevacizumab (BVZ), BVZ + 5-Fu, and BVZ + MMC on type I collagen alpha 1 (Col1A1) mRNA in human Tenon's fibroblasts (HTFs). ${ }^{*} P<0.05$.

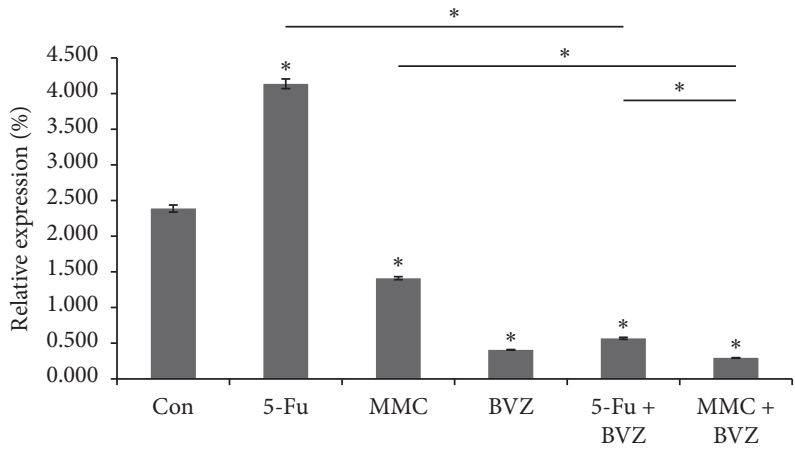

(a)

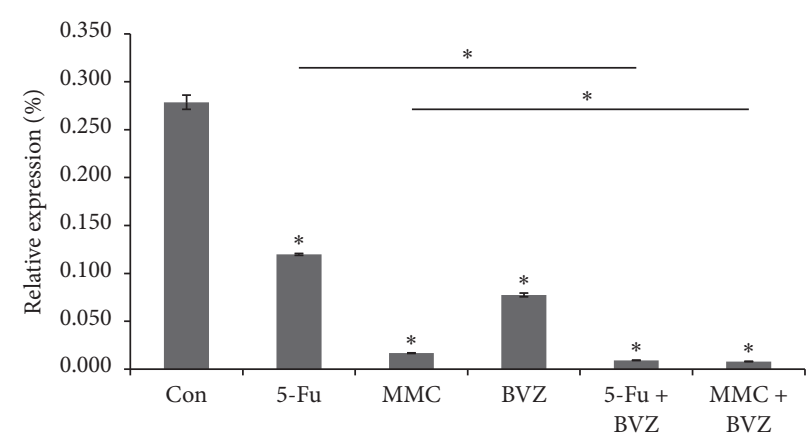

(b)

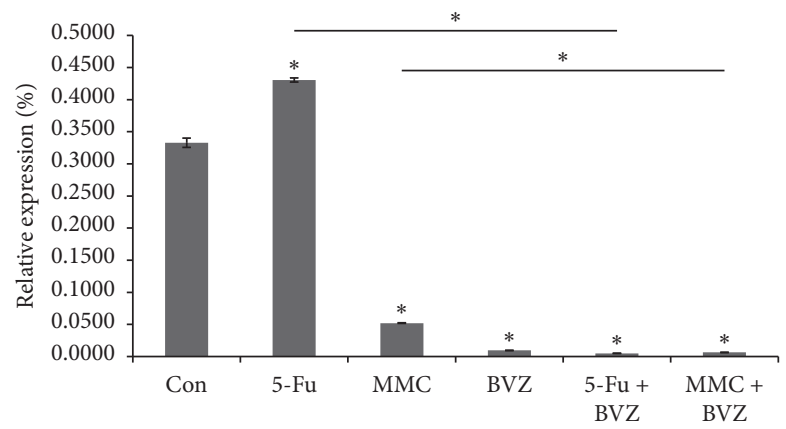

(c)

Figure 6: Effect of 5-fluorouracil (5-Fu), mitomycin C (MMC), bevacizumab (BVZ), BVZ + 5-Fu, and BVZ + MMC on vascular endothelial growth factor (VEGF), VEGFR1 (Flt-1), and VEGFR2 (KDR) mRNA in human Tenon's fibroblasts (HTFs). ${ }^{*} P<0.05$. (a) Flt-1 mRNA\%. (b) KDR mRNA\%. (c) VEGF mRNA\%.

phase is characterized by significant elevation of the expression of transforming growth factor (TGF)- $\beta 2$ and extracellular matrix genes, with a concurrent reduction in the inflammatory cell infiltration. VEGF-A is the only isoform of VEGF that significantly decreases the expression during the late stage of wound healing process [33], suggesting that it might be involved in the transition from the early to late phases of wound healing processes [11]. VEGF signaling is involved in angiogenesis and fibrosis, which are the two key processes during GFS scar formation $[11,33]$.

Based on these studies, anti-VEGF therapies including $\mathrm{BVZ}$ are expected to delay the healing process of filtering blebs after GFS. Anti-VEGF adjuncts are preliminarily tested in vitro [34], animal studies [12, 35], and small clinical trials [36-40]. The results showed promising reduction of postoperative scar formation. However, due to complex process of wound healing, treatment with one target remains insufficient for GFS. There have been reports regarding the clinical use of $\mathrm{BVZ}$ in combination with 5 -Fu or MMC during GFS [41-43]. Nevertheless, the effects of combined application of anti-VEGF antibody and antimetabolite on HTFs and vascular endothelial cells are worth studying. There are problems on whether these show a better performance in the inhibition of wound scar formation after GFS, as well as their safety and underlying mechanisms. 
This study initially examines the cytotoxicity of BVZ, BVZ combined with 5-Fu, and BVZ combined with MMC drugs in HTFs and HUVECs. The results revealed that low concentrations of BVZ have relatively low cellular toxicity, and the toxicity of BVZ in HTF cells is significantly increased with increasing concentrations. According to the previous reports, this cytotoxicity might be explained by nonspecific IgG-related toxicity [44]. Therefore, a relatively low concentration of BVZ is selected for detecting the cytotoxicity of combination of drugs in HTFs, while a relatively high concentration of BVZ is selected in HUVECs. The cytotoxicity of combined drug is significantly greater than that of single drug. This is different from the results of our previous research study [45]. However, previous experiments evaluated the effects of BVZ in retinal pigment epithelial (RPE) cells. Therefore, the results of this study suggests that the combined application of BVZ and antimetabolites, especially by subconjunctival injection, is considered to be safer when administering at different sites (such as the bilateral sides of the filtering bleb) or at different time points.

This experiment shows that the combination of antiVEGF antibody BVZ and antimetabolites can inhibit scar formation of filtering bleb after GFS. This involves direct inhibition of HTF proliferation and collagen formation. HTF is regarded as an important mediator during the formation of subconjunctival scar after trabeculectomy [23]. The scratchwound assay is used to observe the effects of combined drugs on HTF migration. Meanwhile, their effects on the expression of Col1A1 in HTF are detected. The relative cell migration rate of HTFs in BVZ + 5-Fu group is significantly lower than that of BVZ or 5-Fu groups but was not significantly different from $\mathrm{MMC}$ or $\mathrm{BVZ}+\mathrm{MMC}$ group (i.e., $\mathrm{BVZ}+5-\mathrm{Fu}$ group and $\mathrm{MMC}$ or $\mathrm{BVZ}+\mathrm{MMC}$ group). Similar results are observed by qPCR analysis of Col1A1 mRNA. This meant that the direct inhibitory ability of $\mathrm{BVZ}+5-\mathrm{Fu}$ on scar formation is significantly higher than that of $\mathrm{BVZ}$ or $5-\mathrm{Fu}$, which is comparable with that of MMC. However, the inhibitory ability of $\mathrm{BVZ}+\mathrm{MMC}$ is not greater than that of MMC. The results of this in vitro experiment are consistent with the results of animal experiments [45]. On the other hand, inhibition of filtering bleb scar formation after GFS by combining BVZ and antimetabolites involves indirect inhibition. Increased angiogenesis is associated with filtration failure [46, 47]. Vascular endothelial cells are important cells involved in the process of angiogenesis during wound healing process [48]. Decreased VEGF levels in vascular endothelial cells inhibit the formation of new blood vessels at the trabeculectomy site and reduce the permeability of blood vessels, showing an indirect inhibitory effect on scar formation. The combined drugs have significant inhibitory effects on VEGF levels in HUVECs, which are significantly greater than the use of single-drug antimetabolites.

VEGF is one of the key regulators of angiogenesis, vasculogenesis, and developmental hematopoiesis. VEGF is a mitogen and acts as a survival factor for vascular endothelial cells, promoting vascular endothelial cells and monocyte movement $[49,50]$. VEGF receptors mainly include VEGFR1 (Flt-1) and VEGFR2 (KDR) [51]. VEGFR2 is regarded as a major receptor of VEGF and plays a role in mitosis, angiogenesis, and permeability. VEGFR1 is a negative regulator of VEGF during the early developmental stage. VEGFR1 regulates the concentration of free ligands near cells by blocking the binding of VEGF to VEGFR2 in the form of decoy receptors during embryonic stage [50, 51]. BVZ downregulates cell mitosis and angiogenesis by binding to the transmembrane tyrosine kinase receptors VEGFR1 and VEGFR2 [52]. This study demonstrates that BVZ combined with antimetabolites significantly inhibits the expression of VEGF (R) mRNA in HTFs. The effects of combined drugs are greater than those of 5-Fu or MMC alone. BVZ + MMC has a stronger inhibitory effect on VEGFR1 mRNA expression in HTFs than BVZ + 5-Fu. For VEGFR2 mRNA expression in HTFs, the inhibitory effect of combined drugs is greater than that of BVZ, while the effects of BVZ, BVZ+MMC, and $\mathrm{BVZ}+5-\mathrm{Fu}$ are comparable in inhibiting VEGF mRNA formation in HTFs. Further research regarding the mechanisms of combined drugs is warranted.

This is an in vitro study conducted to observe the safety of BVZ combined with 5-Fu and BVZ combined with MMC and to evaluate their inhibitory effects on scar formation after GFS. Our experiments suggest that the antiscarring effect of BVZ combined with 5-Fu is more significant than that of BVZ or 5-Fu alone, which is comparable with MMC. However, the inhibitory effects on scar formation by BVZ combined with MMC are not greater than MMC. In addition, the results of our experiments suggest that combination of BVZ and antimetabolites at different sites (such as subconjunctival injection on bilateral sides of the filtering bleb) or time points are safer when considering their cytotoxicity. Our research also contributes to a more comprehensive understanding regarding the role of $\mathrm{BVZ}$ combined with antimetabolites during wound healing process.

\section{Data Availability}

All the data supporting the findings of this study are available within the article.

\section{Conflicts of Interest}

The authors declare that there are no conflicts of interest regarding the publication of this article.

\section{Acknowledgments}

This study was supported by the Key Project Funds for Scientific Research of the Shanghai Municipal Committee of Health and Family Planning (Grant no. 201640027).

\section{References}

[1] G. L. Skuta and R. K. Parrish II, "Wound healing in glaucoma filtering surgery," Survey of Ophthalmology, vol. 32, no. 3, pp. 149-170, 1987

[2] K. Schwartz and D. Budenz, "Current management of glaucoma," Current Opinion in Ophthalmology, vol. 15, no. 2, pp. 119-126, 2004.

[3] M. Y. Kahook, J. S. Schuman, and R. J. Noecker, "Needle bleb revision of encapsulated filtering bleb with bevacizumab," 
Ophthalmic Surgery, Lasers and Imaging Retina, vol. 37, no. 2, pp. 148-150, 2006.

[4] D. S. Grewal, R. Jain, H. Kumar, and S. P. S. Grewal, "Evaluation of subconjunctival bevacizumab as an adjunct to trabeculectomy," Ophthalmology, vol. 115, no. 12, pp. 2141-2145, 2008.

[5] A. Kakehashi, S. Inoda, C. Mameuda et al., "Relationship among VEGF, VEGF receptor, AGEs, and macrophages in proliferative diabetic retinopathy," Diabetes Research and Clinical Practice, vol. 79, no. 3, pp. 438-445, 2008.

[6] R. C. Tripathi, J. Lixa, B. J. Tripathi, K. V. Chalam, and A. P. Adamis, "Increased level of vascular endothelial growth factor in aqueous humor of patients with neovascular glaucoma," Ophthalmology, vol. 105, no. 2, pp. 232-237, 1998.

[7] S. A. Vinores, C. C. Chan, M. A. Vinores et al., "Increased vascular endothelial growth factor (VEGF) and transforming growth factor beta (TGFbeta) in experimental autoimmune uveoretinitis: upregulation of VEGF without neovascularization," Journal of Neuroimmunology, vol. 89, no. 12, pp. 43-50, 1998 .

[8] R. N. Frank, "Growth factors in age-related macular degeneration: pathogenic and therapeutic implications," Ophthalmic Research, vol. 29, no. 5, pp. 341-353, 1997.

[9] M. Murakami, S. Iwai, S. Hiratsuka et al., "Signaling of vascular endothelial growth factor receptor-1 tyrosine kinase promotes rheumatoid arthritis through activation of monocytes/macrophages," Blood, vol. 108, no. 6, pp. 1849-1856, 2006.

[10] D. Beddy, R. W. G. Watson, J. M. Fitzpatrick, and P. R. O'Connell, "Increased vascular endothelial growth factor production in fibroblasts isolated from strictures in patients with Crohn's disease," British Journal of Surgery, vol. 91, no. 1, pp. 72-77, 2004.

[11] M. Kim, C. Lee, R. Payne, B. Y. J. T. Yue, J.-H. Chang, and $H$. Ying, "Angiogenesis in glaucoma filtration surgery and neovascular glaucoma: a review," Survey of Ophthalmology, vol. 60, no. 6, pp. 524-535, 2015.

[12] Z. Li, T. Van Bergen, S. Van de Veire et al., "Inhibition of vascular endothelial growth factor reduces scar formation after glaucoma filtration surgery," Investigative Opthalmology \& Visual Science, vol. 50, no. 11, pp. 5217-5225, 2009.

[13] N. Nilforushan, M. Yadgari, S. K. Kish, and N. Nassiri, "Subconjunctival bevacizumab versus mitomycin $\mathrm{C}$ adjunctive to trabeculectomy," American Journal of Ophthalmology, vol. 153, no. 2, pp. 352-357, 2012.

[14] H. Nomoto, F. Shiraga, N. Kuno et al., "Pharmacokinetics of bevacizumab after topical, subconjunctival, and intravitreal administration in rabbits," Investigative Opthalmology \& Visual Science, vol. 50, no. 10, pp. 4807-4813, 2009.

[15] J. Jurkowska-Dudzinska, E. Kosior-Jarecka, and T. Zarnowsli, "Comparison of the use of 5-fluorouracil and bevacizumab in primary trabeculectomy: results at 1 year," Clinical \& Experimental Ophthalmology, vol. 40, no. 4, pp. e135-e142, 2012.

[16] W. Jing and P. Harasymowycz, "Subconjunctival bevacizumab injection in glaucoma filtering surgery: a case control series," ISRN Ophthalmology, vol. 2013, Article ID 384134, 6 pages, 2013.

[17] F. Grehn and G. Hollo, P. et al., Factors affecting the outcome of trabeculectomy: an analysis based on combined data from two phase III studies of an antibody to transforming growth factor beta2, CAT-152," Ophthalmology, vol. 114, no. 10, pp. 1831-1838, 2007, Khaw.

[18] S. Smith, P. A. D'Amore, and E. B. Dreyer, "Comparative toxicity of mitomycin C and 5-fluorouracil in vitro," American Journal of Ophthalmology, vol. 118, no. 3, pp. 332-337, 1994.
[19] G. L. Skuta, C. C. Beeson, E. J. Higginbotham et al., "Intraoperative mitomycin versus postoperative 5 -fluorouracil in high-risk glaucoma filtering surgery," Ophthalmology, vol. 99, no. 3, pp. 438-444, 1992.

[20] H. M. Marey and A. F. Ellakwa, "Intravitreal bevacizumab with or without mitomycin C trabeculectomy in the treatment of neovascularglaucoma," Clinical Ophthalmology, vol. 5, pp. 841-845, 2011

[21] W. Suh and C. Kee, "The effect of bevacizumab on the outcome of trabeculectomy with 5-Fluorouracil," Journal of Ocular Pharmacology and Therapeutics, vol. 29, no. 7, pp. 646-651, 2013.

[22] M. S. Spitzer, B. Wallenfels-Thilo, A. Sierra et al., "Antiproliferative and cytotoxic properties of bevacizumab on different ocular cells," British Journal of Ophthalmology, vol. 90, no. 10, pp. 1316-1321, 2006.

[23] P. J. Lama and R. D. Fechtner, "Antifibrotics and wound healing in glaucoma surgery," Survey of Ophthalmology, vol. 48, no. 3, pp. 314-346, 2003.

[24] N. Li, J. Cui, X. Duan, H. Chen, and F. Fan, "Suppression of type I collagen expression by miR-29b via PI3K, Akt, and Sp1 pathway in human Tenon's fibroblasts," Investigative Opthalmology \& Visual Science, vol. 53, no. 3, pp. 1670-1678, 2012.

[25] L. Cao, H. Liu, D. S. C. Lam, G. H.-F. Yam, and C.-P. Pang, "In vitro screening for angiostatic potential of herbal chemicals," Investigative Opthalmology \& Visual Science, vol. 51, no. 12, pp. 6658-6664, 2010.

[26] J. P. Tong, D. S. Lam, W. M. Chan, K. W. Choy, K. P. Chan, and C. P. Pang, "Effects of triamcinolone on the expression of VEGF and PEDF in human retinal pigment epithelial and human umbilical vein endothelial cells," Molecular Vision, vol. 12, pp. 1490-1495, 2006.

[27] A. Wang, N. X. Landén, F. Meisgen et al., "MicroRNA-31 is overexpressed in cutaneous squamous cell carcinoma and regulates cell motility and colony formation ability of tumor cells," PLoS One, vol. 9, no. 7, Article ID e103206, 2014 Jul 28.

[28] R. Ian Freshney, Culture of Animal Cells: A Manual of Basic Technique, Wiley-Liss, Inc., Hoboken, NJ, USA, 4th edition, 1994.

[29] E. M. Addicks, H. A. Quigley, W. R. Green, and A. L. Robin, "Histologic characteristics of filtering blebs in glaucomatous eyes," Archives of Ophthalmology, vol. 101, no. 5, pp. 795-798, 1983.

[30] L. K. Seibold, M. B. Sherwood, and M. Y. Kahook, "Wound modulation after filtration surgery," Survey of Ophthalmology, vol. 57, no. 6, pp. 530-550, 2012.

[31] P. Bao, A. Kodra, M. Tomic-Canic, M. S. Golinko, H. P. Ehrlich, and H. Brem, "The role of vascular endothelial growth factor in wound healing," Journal of Surgical Research, vol. 153, no. 2, pp. 347-358, 2009.

[32] T. A. Wilgus, A. M. Ferreira, T. M. Oberyszyn, V. K. Bergdall, and L. A. DiPietro, "Regulation of scar formation by vascular endothelial growth factor," Laboratory Investigation, vol. 88, no. 6, pp. 579-590, 2008.

[33] L. F. Seet, S. N. Finger, S. W. L. Chu, L. Z. Toh, and T. T. Wong, "Novel insight into the inflammatory and cellular responses following experimental glaucoma surgery: a roadmap for inhibiting fibrosis," Current Molecular Medicine, vol. 13, no. 6, pp. 911-928, 2013.

[34] E. C. O’Neill, Q. Qin, N. J. Van Bergen et al., “Antifibrotic activity of bevacizumab on human Tenon's fibroblasts in vitro," IInvestigative Opthalmology \& Visual Science, vol. 51, no. 12, pp. 6524-6532, 2010. 
[35] F. Memarzadeh, R. Varma, L.-T. Lin et al., "Postoperative use of bevacizumab as an antifibrotic agent in glaucoma filtration surgery in the rabbit," Investigative Opthalmology \& Visual Science, vol. 50, no. 7, pp. 3233-3237, 2009.

[36] J. B. Jonas, U. H. Spandau, and F. Schlichtenbrede, "Intravitreal bevacizumab for filtering surgery," Ophthalmic Research, vol. 39, no. 2, pp. 121-122, 2007.

[37] S. Sengupta, R. Venkatesh, and R. D. Ravindran, "Safety and efficacy of using off-label bevacizumab versus mitomycin $\mathrm{C}$ to prevent bleb failure in a single-site phacotrabeculectomy by a randomized controlled clinical trial," Journal of Glaucoma, vol. 21, no. 7, pp. 450-459, 2012.

[38] E. Vandewalle, L. Abegao Pinto, T. Van Bergen et al., "Intracameral bevacizumab as an adjunct to trabeculectomy: a 1-year prospective, randomised study," British Journal of Ophthalmology, vol. 98, no. 1, pp. 73-78, 2014.

[39] G. Fakhraie, H. Ghadimi, Y. Eslami et al., "Short-term results of trabeculectomy using adjunctive intracameral bevacizumab," Journal of Glaucoma, vol. 25, no. 3, pp. e182-e188, 2016.

[40] Z. Vahedian, M. Mafi, G. Fakhraie et al., "Short-term results of trabeculectomy using adjunctive intracameral bevacizumab versus mitomycin C: a Randomized controlled trial," Journal of Glaucoma, vol. 26, no. 9, pp. 829-834, 2017.

[41] A. M. Saeed and T. Aboulnasr, "Subconjunctival bevacizumab to augment trabeculectomy with mitomycin $\mathrm{C}$ in the management of failed glaucoma surgery," Clinical Ophthalmology, vol. 8, pp. 1745-1755, 2014.

[42] Y. Takihara, M. Inatani, T. Kawaji et al., "Combined intravitreal bevacizumab and trabeculectomy with mitomycin $\mathrm{C}$ versus trabeculectomy with mitomycin $\mathrm{C}$ alone for neovascular glaucoma," Journal of Glaucoma, vol. 20, no. 3, pp. 196-201, 2011.

[43] F. Freiberg, J. Matlach, F. Grehn, T. Klink, and S. Karl, "Postoperative subconjunctival bevacizumab injection as an adjunct to 5-fluorouracil in the management of scarring after trabeculectomy," Clinical Ophthalmology, vol. 7, pp. 12111217, 2013.

[44] C. V. Fischer, V. Mans, M. Horn, S. Naxer, A. Klettner, and C. van Oterendorp, "The Antiproliferative effect of bevacizumab on human Tenon fibroblasts is not mediated by vascular endothelial growth factor inhibition," Investigative Opthalmology \& Visual Science, vol. 57, no. 11, pp. 4970-4977, 2016.

[45] L. Zuo, J. Zhang, and X. Xu, "Combined application of bevacizumab and mitomycin $\mathrm{C}$ or bevacizumab and 5-fluorouracil in experimental glaucoma filtration surgery," Journal of Ophthalmology, vol. 2018, Article ID 8965709, 13 pages, 2018.

[46] L. B. Cantor, A. Mantravadi, D. WuDunn, K. Swamynathan, and A. Cortes, "Morphologic classification of filtering blebs after glaucoma filtration surgery: the indiana bleb appearance grading scale," Journal of Glaucoma, vol. 12, no. 3, pp. 266271, 2003.

[47] J. R. Marks, J. C. K. Clarke, T. Peto, D. Minassian, and P. T. Khaw, "Postoperative increased bleb vascularity persists for over one year and has implications for intraocular pressure control," Investigative Ophthalmology \& Visual Science, vol. 45, p. U377, 2004.

[48] A. F. Karamysheva, "Mechanisms of angiogenesis," Biochemistry (Moscow), vol. 73, no. 7, pp. 751-762, 2008.

[49] N. Ferrara, H.-P. Gerber, and J. LeCouter, "The biology of VEGF and its receptors," Nature Medicine, vol. 9, no. 6, pp. 669-676, 2003.
[50] R. Robert Jr., "VEGF receptor protein-tyrosine kinases: structure and regulation," Biochemical and Biophysical Research Communications, vol. 375, no. 3, pp. 287-291, 2008.

[51] S. A. Park, M. S. Jeong, K.-T. Ha, and S. B. Jang, "Structure and function of vascular endothelial growth factor and its receptor system," BMB Reports, vol. 51, no. 2, pp. 73-78, 2018.

[52] D. J. Pieramici and M. D. Rabena, "Anti-VEGF therapy: comparison of current and future agents," Eye, vol. 22, no. 10, pp. 1330-1336, 2008. 




The Scientific World Journal
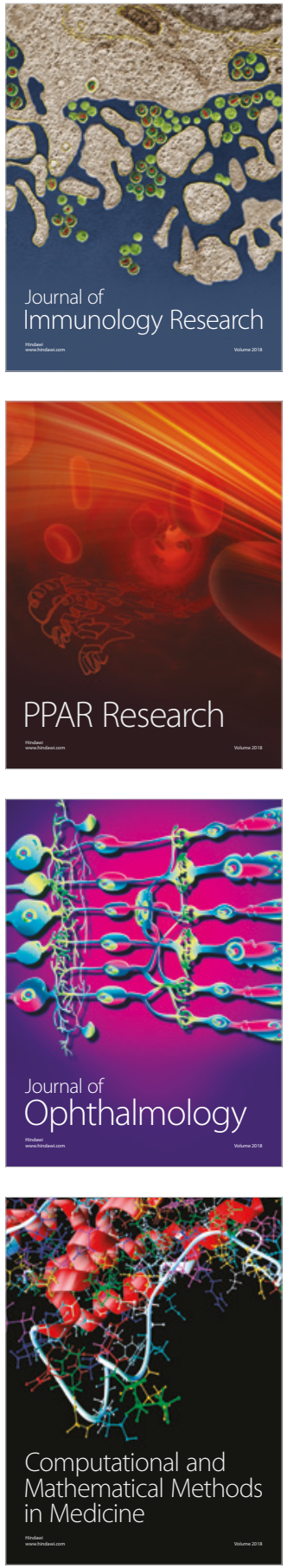

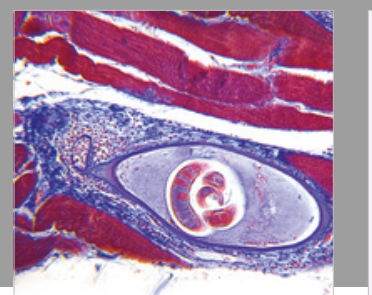

Gastroenterology Research and Practice

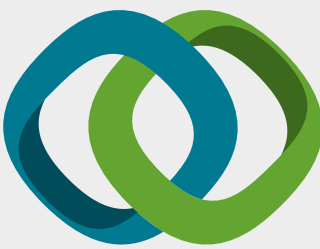

\section{Hindawi}

Submit your manuscripts at

www.hindawi.com
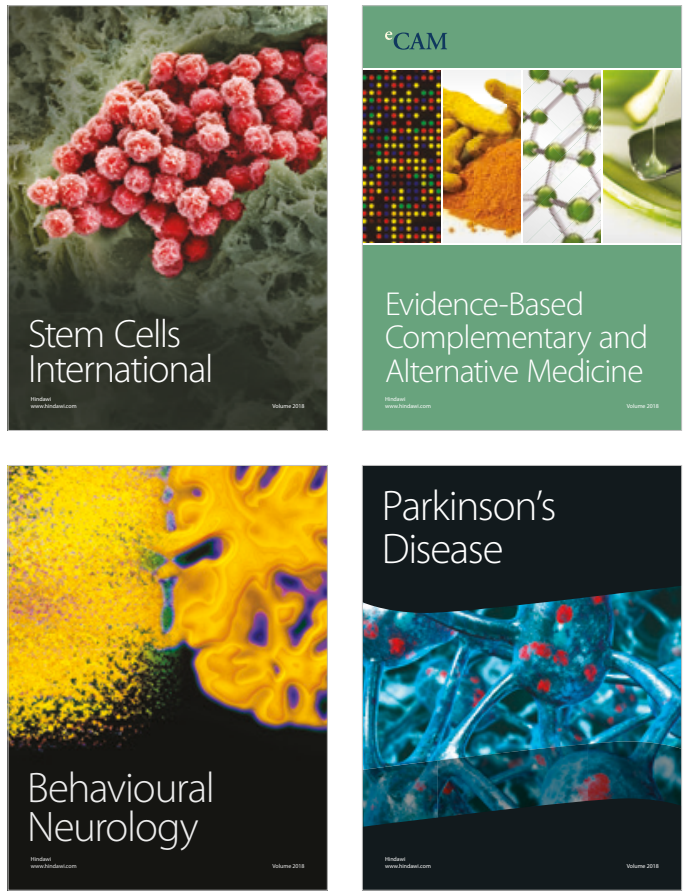

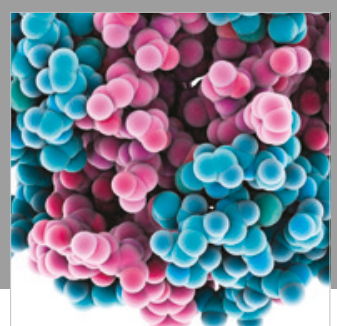

ournal of

Diabetes Research

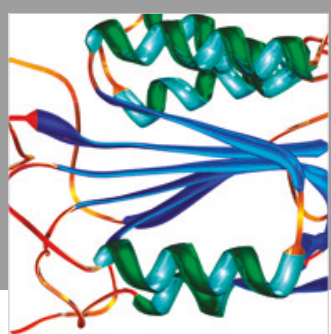

Disease Markers
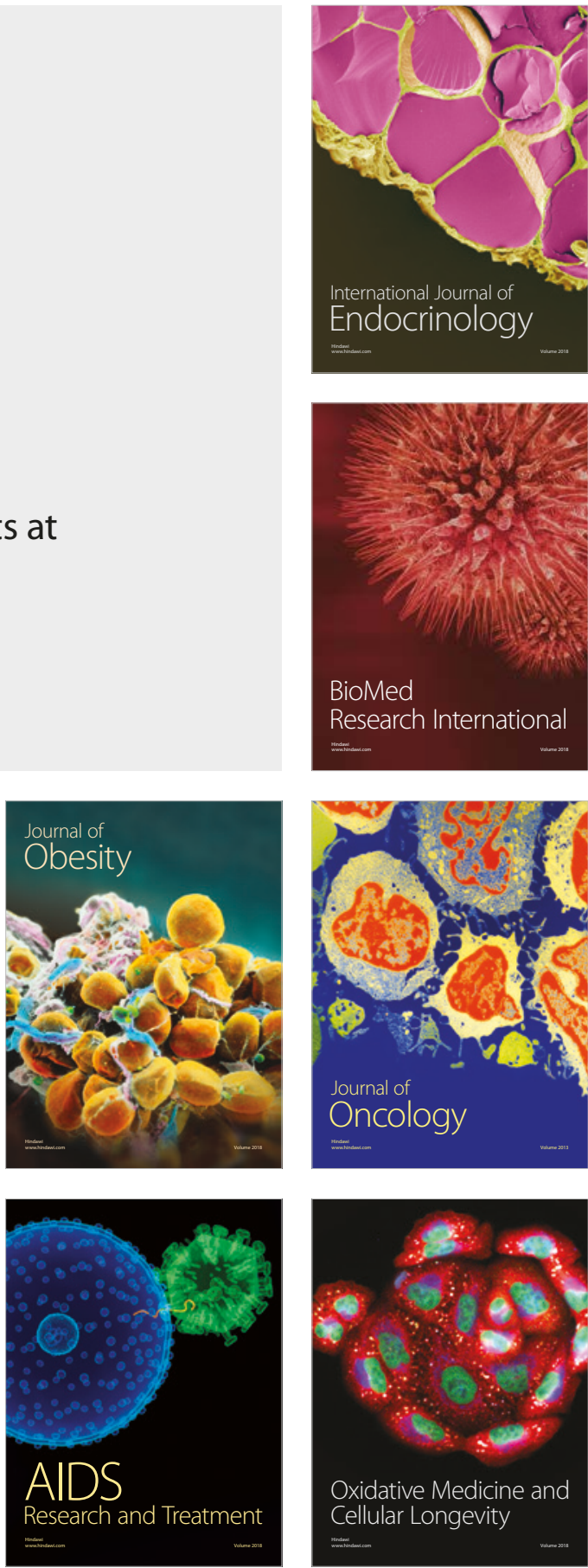